\title{
Bosnian Immigrants' Acculturation To Consumer Culture Experienced in İzmir
}

\author{
Ayla ÖZHAN DEDEOĞLU1', Elif ÜSTÜNDAĞLI²
}

\begin{abstract}
Consumer acculturation refers to socialization process in which an immigrant learns the consumption related behaviors and values of the host culture and integrate them with their original culture. The present study aims to contribute to the literature by studying consumer acculturation of Bosnian immigrants who had to migrate because of negative political and religious environment, in addition to socio-economical problems, in their home country. The study was conducted in Izmir/Turkey. Findings reveal that Bosnian immigrants have integrative attitudes toward Turkish culture while maintaining their original culture. They try to shield their community from consumer culture experienced in Izmir, as well. Findings also show that socio-historical factors are acculturative agents.
\end{abstract}

Key Words: consumer acculturation, consumer culture, bosnian immigrants

\section{INTRODUCTION}

Considerable research has been conducted to understand of consumer acculturation, its antecedents and indicators, agents that influence its process (e.g. Askegaard et al,, 2005; Ustuner et al., 2007; Penaloza, 1994; Ger et al., 1998). Most of the research in this field studied migrations of people from less developed countries/regions to the developed ones pursuing a quest for a more affluent life. Since ethnic flows mostly occur toward the more affluent western part of the world, researchers mostly studied immigrants' adaptation to Western consumer cultural environments. In these studies, immigrants have taken their decision to migrate in a context of free will, although driven mostly by economical problems.

Despite all the great deal of research effort, there remains a dearth of research that examines the acculturation of consumers who had or needed to migrate because of a negative ethnic and religious environment, as well as socio-economical problems, in their home country. Past and ongoing ethnic and religious conflicts at home are suggested to institute nationalist narratives and heighten interest in ethnic roots (Lieberman, 2006) and a sense of ethnic self-defense whether immigrants face real discrimination in host country or not. As a result of this, different patterns of consumer acculturation might be observed. The present study attempts to fill this gap by exploring con- sumer acculturation of Bosnian immigrants in Turkey. Makrides (2007) remarked that Bosnian Muslims' great suffering due to ethnic cleansing attempts during the 1992-1995 war rendered their claim to a European Muslim identity even stronger.

The research questions are as follows: to what extent are Bosnian immigrant consumers who migrate due reasons but 'free' will and who have ongoing ethnic and religious conflicts at their home country acculturated to Turkish consumer culture, what is the relationship between immigrant's tendency of original cultural maintenance and acculturation to Turkish culture and what are the antecedents that influence their acculturation? The second question is designed help to develop inferences about the influence of socio-historical proximity on their acculturation to Turkish culture.

\section{CONSUMER ACCULTURATION}

Acculturation is a process of cultural and psychological change that follows intercultural contact (Berry, 2003). As a result of intercultural and continuous first hand contact, original culture patterns of either minority or both minority and dominant groups do change (Ogden et al., 2004). Ustuner and Holt (2007) remark that acculturation refers generally to what happens when people socialized in a minority culture migrate and so come into continuous first-hand contact with 
a new dominant culture.

Consumer acculturation, a subset of acculturation, refers to a socialization process in which an immigrant learns the consumption related behaviors, attitudes and values of the host culture and integrate them with their original culture (Penaloza, 1994; Ogden et al., 2004). The study of consumer acculturation primarily focuses on cultural adaptation as manifest in the marketplace and examines the consumer learning processes that are affected by the interactions between two or more cultures (Penaloza, 1994; Ucok et al., 2006).

Berry et al. (1989)'s framework tries to explain acculturation based on the tendency of the acculturating group to maintain its cultural identity, i.e. original culture maintenance (OCM), and/or to develop cultural contact with the hosting group, i.e. host culture adherence (HCA). Orientations of the acculturating group are categorized into four groups; assimilation, integration, separation, and marginalization. Assimilation occurs when immigrants can proactively adopt the host culture by getting in close contact and do not seek to maintain their cultural identity. When immigrants choose both cultural maintenance and inter-group contact with the hosting group, they are said to be integrated. Integration occurs when immigrants develop inter-cultural contact on their free will and the hosting group is tolerant and open to cultural diversity. Integration is a bi-directional process, which acknowledges that both cultures change over time, while assimilation is unidirectional, towards the dominant group (Jun et al., 1994). Separation is the way when cultural maintenance is sought while avoiding involvement with others. Marginalization exists when immigrants distance themselves from both cultures and do seek neither cultural maintenance nor interaction with others. Immigrants can become marginal mostly in situations when they are segregated, discriminated and/or when there is little chance to maintain cultural identity (Berry, 1997; Berry et al., 2006; Palumbo et al., 2004; Gronhaug et al., 1993; Wilson, 2007; Shoham et al., 2009; Ustuner et al., 2007; Sandikci et al., 2006). The hosting group's attitude toward the acculturation process of immigrants can occur in ways of "melting pot" idea, multi-culturalism, discrimination, and segregation. Sandikci et al. (2006) and Penaloza (1994) noted that Berry's acculturation model has emerged as the dominant conceptual framework guiding consumer acculturation studies.

Berry's framework is criticized because it perceives acculturation as a linear process with four possible outcomes and use a dichotomous (host and ethnic minority) perspective, rather than a continuous pers- pective (Sandikci et al., 2006; Askegaard et al., 2005; Jun et al., 1993; Jun et al., 1994; Ucok et al., 2006). Based on the findings of her ethnographic study, Penaloza (1994) showed that consumer acculturation does not necessarily lead to assimilation and proposed an alternative to this framework. Based on the proposal that immigrants go through a process in which they move, translate and learn to live in the host culture, she suggested four consumer acculturation practices: resistance (against the practices of the host group), acculturation (adopt practices of the host group while maintaining their identity), assimilation (adopt practices of the host group while leaving their identity), and physical (spatial) segregation. Supporting the idea of that rather than conforming to one culture, people constantly negotiate cultural identities, i.e. "swap culture" (Oswald, 1999), she found that immigrants' consumption patterns might indicate assimilation at some occasions and resistance at some others. Some other studies also demonstrated that consumers can move between different social worlds without necessarily conforming to one culture and immigrants commingle various consumption practices in different ways to form identities (e.g. Askegaard et al., 2005; Ger et al., 1998; Penaloza, 1994). Jun et al (1994) suggested that the acculturation process starts from the "home" culture but does not head linearly for the "host" culture, as it may progress rapidly on occasion or it may move backward at any time during the process. Consistent with this perspective, Lindridge (2009) and Sandikci et al (2006) demonstrated that the acculturating group alters behavior to adapt across consumption contexts. Their findings reveal that acculturation is a "dialogical process that involves a constant moving back and forth between incompatible cultural positions (Sandikci et al., 2006)". Furthermore, Askegaard et al. (2005) challenged Berry's framework and introduced 'postassimilationist view', that regards consumer acculturation as a dynamic and multidimensional process that includes ongoing cultural negotiation.

A distinction between behavioral acculturation and attitudinal acculturation is also made in the consumer acculturation literature (Gentry et al., 2002; Jun et al., 1993). Jun et al. (1993) proposed that the process of behavioral acculturation may not coincide with the process of attitudinal acculturation; i.e. one's consumption pattern could be close to the host's cultural values while the ethnic identification is close to the old culture. They found that "cultural/ethnic identification" (attitudinal in nature) and "level of acculturation", i.e. the degree to which an individual conforms to the host culture, (behavioral in nature) are 
distinct constructs. Jun et al. (1994) also noted that behavioral acculturation is expected be faster than attitudinal acculturation (self-identification). Besides, immigrants can be rather acculturated to the host culture but still maintain strong ethnic identification (Ogden et al., 2004).

\subsection{Antecedents and Indicators of Consumer Acculturation}

Some factors, either individually or in combination, that have been considered as antecedents and/or indicators of consumer acculturation are ethnic identification, cultural pride and heritage, language and media usage, intercultural contact, area and length of residence, perceived discrimination, religion, social class, and demographic factors such as age, generation, and income (e.g. Ogden et al., 2004; Berry et al., 2006; Penaloza, 1994).

While ethnicity is an objective description and refers to a group with common national or religious backgrounds, ethnic identity is more subjective and refers to individuals' self-identification and affiliation with a cultural group (Ogden et al., 2004). Ogden et al. (2004) used the term "objective ethnicity" to define ethnicity which can be observed through some objective measures, such as similarities in language, surname, region of origin, or visual phenotypical distinctions (skin color, and hair color etc.), yet with a warning that although objective, using these measures often lead to misclassification. Instead of it, ethnic self-identification is suggested to reflect a 'sense' of real identity (Askegaard et al., 2005) i.e. the beliefs of individuals about their perception of cultural reality (Ogden et al., 2004).

Askegaard et al. (2005) suggested the term postassimilationist ethnicity and asserted that through ongoing cultural negotiation or "culture swapping", ethnicity becomes a consumer choice, albeit not a free and unconstrained one. Some researchers observed consumer ethnic identities are fluid and diverse and combine both minority and dominant cultures during immigrants' various encounters with the dominant culture.(e.g. Cherrier et al., 2009). Some other researchers, argued for a concept of hybrid identities (e.g. Askegaard et al., 2005) that can be formed through "the junction of multiple and diverse cultural and subcultural forces, groups, and same-different tensions (Ger et al., 1998)". Sandıkcı et al. (2006) argued that consumer acculturation is a "dialogical process that involves a constant back and forth movement between incompatible cultural positions". Similarly, the conceptualization of dynamic inbetweeness supports dialogical perspective (Anderson, 2008).
Several studies revealed that individuals' sense of cultural pride and ethnic belongingness, and tendency to retain the identification of the culture of origin cut down their adoption of the host culture (e.g. Berry et al., 2006; Shoham et al., 2009; Wilson, 2007; Jun et al., 1994; Ogden et al., 2004). Wilson (2007) noted that cultural pride does not require one to have specific knowledge of one's culture and their culture's artifacts (i.e., cultural heritage) but rather simply a claimed ancestry. Immigrants who have high level of cultural pride and/or maintained their cultural heritage are more likely to maintain their original culture.

Since language is the primary medium for the flow of cultural elements, language preference and proficiency are viewed as one of the most important indicators of acculturation (Ogden et al., 2005). Immigrants who prefer their ancestral language in daily life are found to be less likely to adhere to host culture and more likely to maintain their original culture (e.g. Berry et al., 2006; Quester et al., 2001; Palumbo et al., 2004; Wilson, 2007; O'Guinn et al., 1985). As long as the immigrant uses the language of the host culture in most life themes, develops intercultural contacts, and use mainstream media, s/he is exposed to the host culture, and learns it (Chung, 2000).

The extent of intercultural contact is derived by the length and depth of the contact. Several studies revealed that the longer immigrants are in the new culture, the more they are attitudinally and behaviorally acculturated or the less they have difficulty adapting to the new culture (e.g. Berry et al., 2006; Penaloza, 1994; Shoham et al., 2009). Yet, length of stay do not necessarily determine adaptation; immigrants who live in neighborhoods with a greater similar ethnic density and a close-knit community, and who prefer contact with their peers instead of ethnically different people are also found to be less acculturated(Wilson, 2007; Ustuner et al., 2007; Jun et al., 1994). The amount of interaction with the host culture is found to be lower than if they lived in an interracial neighborhood (Hmida et al., 2009; Tari et al., 2008). Furthermore, immigrants who are in closer contact with people living in their country rather than members of the host country may be less acculturated. On the other hand, as Penaloza (2008) demonstrated, cultural changes may occur at both parties; she observed that "as NonLatino/a consumers consume Mexican American culture at many of the sites, they exert profound social legitimizing effects supporting and validating Mexican American cultures" (p.34).

In addition to immigrant's ethnic self-identification, others' designation of the individual as member of certain ethnic group is also found to influence one's 
felt affiliation with one ethnic group (Penaloza, 1994). Those who occupy socially recognized designations continue to acculturate to the host and/or dominant culture (Ogden et al.. 2004). On the other hand, those who ever felt alienated because of their race or ethnic background may withhold themselves in the process of acculturation (e.g. Wamwara-Mbugua et al., 2006). In a study, immigrants who have felt discriminated are found to be more likely to purchase products that are advertised in their own language (Wilson, 2007). Another reaction against felt discrimination is to internalize the stigma of being main-stream's "other" and try to decrease their differences by assimilating products in an attempt to fit in (Penaloza, 1994).

Demographics may impact consumer acculturation. Past findings suggest that male, young, more affluent, and higher educated immigrants learn the new culture and acculturate faster than female, old, less affluent, lower educated immigrants (e.g. Berry, 1997; Palumbo et al., 2004; Jun et al., 1993; Penaloza, 1995). Furthermore, immigrants who arrive at early ages and members of the second generation who were born in the host country learn the language and acculturate rapidly (e.g. Palumbo et al., 2004; Berry et al., 2006; Hmida, 2006).

\subsection{Agents of Consumer Acculturation}

Factors that act as essential elements, i.e. agents, in the process of consumer acculturation are the household, institutions, media, marketing activities, global consumer culture, and socio-cultural structures such class position and conflicting ideologies, historical factors (Askegaard et al., 2005; Penaloza, 1994; Ucok et al., 2006; Ustuner et al., 2007; Hmida et al., 2009). A household brings together individuals of various characteristics, resources and skills, who socially support each other (Penaloza, 1994). In a study, it was observed that household provisioning is a vehicle through which old and new culture is shared, constructed and maintained (Crockett et al., 2004). Additionally, as the immigrant chooses to participate in the institutions (e.g. school, stores etc.) other than family, he/she acculturate faster.

Marketing activities and marketplace operate as effective cultural change agents (Penaloza et al., 1999). Penaloza (1994) demonstrated how marketers facilitate the institutionalization of the culture of the immigrants in the host country by targeting them with market offerings associated with their culture. Marketplace serves not only the site for market transactions, but also for the negotiation of intercultural relationships (Penaloza et al., 1999). Media enables immigrants to gain a better understanding of the so- ciety. Moreover, media relevant to their ethnic cultural community give them the opportunity to remain in contact with their country and culture of origin (Hmida et al., 2009).

The immigrants' identity constructs are influenced by competing ideologies of home and host cultures on consumption patterns. A third agent, as suggested by Askegaard et al (2005), is the transnational consumer culture. In consumer culture, consumption has become a signification and communication tool (Baudrillard, 1997). Products are consumed as social signifiers, not only as material objects. In a quest to construct their actual and ideal social self, maintain specific life themes and reach desired life projects, individuals, ascribe meanings to products and negotiate them. These meanings are embodied and negotiated by consumers in particular social situations, roles and relationships (Arnould et al., 2005). Via consumption they also differentiate themselves among their environment. Askegaard et al. (2005) revealed that transnational consumer culture is experienced as a sort of neutral cultural ground and an enrichment of consumption opportunities accessible to people of the host country and immigrants alike.

Social and historical factors are acculturative agents as well (Ustuner et al., 2007; Ozcaglar-Toulouse et al., 2009). In their 'dominated consumer acculturation' model, Ustuner et al. (2007) demonstrated that socio-cultural structures such as lack of economic, social, and cultural capital, ideological conflicts and modern consumer culture are central in the process of consumer acculturation. Additionally, OzcaglarToulouse et al. (2009) also revealed that immigrants' acculturation is also influenced by historical tensions between the host and home countries, and stigmas associated with each other's cultures.

\section{FIELD STUDY}

Despite all the great deal of research effort, there remains a dearth of research that examines the acculturation of consumers who had or needed to migrate because of instable and negative political and religious environment, as well as socio-economical problems, in their home country. Past and ongoing ethnic and religious conflicts at home are suggested to institute nationalist narratives and heighten interest in ethnic roots (Lieberman, 2006) and a sense of ethnic self-defense whether immigrants face real discrimination in host country or not. As a result of this, different patterns of consumer acculturation might be observed. The present study attempts to fill this gap by exploring consumer acculturation of Bosnian immig- 
rants in Turkey. Makrides (2007) remarked that Bosnian Muslims' great suffering due to ethnic cleansing attempts during the 1992-1995 war rendered their claim to a European Muslim identity even stronger.

The research questions are as follows: to what extent are Bosnian immigrant consumers who migrate due reasons but 'free' will and who have ongoing ethnic and religious conflicts at their home country acculturated to Turkish consumer culture, what is the relationship between immigrant's tendency of original cultural maintenance and acculturation to Turkish culture and what are the antecedents that influence their acculturation? By answering the second question, it is intended to develop inferences about the influence of socio-historical proximity on their acculturation to Turkish culture.

Bosnia-Herzegovina is seen as a stage for encounters, confrontations, symbiosis, transition and/or conflict between different religions, national mythologies, and concepts of statehood (Velikonja, 2003).After the conquest of Bosnia in 1463, the Ottoman Empire ruled for three centuries. Bosnia was gone under Austro-Hungarian Rule in 1878. Following the World War I, Bosnia and Herzegovina joined the Kingdom of Serbs, Croats and Slovenes (soon renamed Yugoslavia) in 1918 (Riedlmayer, 1993). Following conquest of Nazi forces and turbulent years, at the end of the World War II the Socialist Federal Republic of Yugoslavia was established and Bosnia and Herzegovina became one of six constituent republics. With the fall of the Soviet Union, Yugoslavia started to break-up and nationalistic movements took precedence. Soon after Bosnia and Herzegovina's declaration of sovereignty in 1992 and a tense period of escalating tensions and sporadic military incidents, war began in Sarajevo (Riedlmayer, 1993) and lasted until 1995. Research and Documentation Center (RDC) statistics revealed that Bosniaks suffered more than Croat and Serbs did. Ethnic cleansing and civil rights violations against nonSerbs were documented during the war.

Because of South Slavs' encounters with Islam and Turkish culture, monarchy and socialist regimes, frequent conquests and wars, the population's composition has changed. A native Slavic-speaking Muslim community emerged, and the area has experienced several religious and political instable periods. During the history, the area has undergone tensions and turbulences, resulting in several mass immigration movements. According to Wood (1994), Bosnia and Herzegovina's has the highest forced immigration rates $(57 \%)$ in the world in 1993 . Bosnians migrated to Anatolia in the year of 1804 , between 1806 and 1812, and in 1826, and between 1950 and 1970. Anot- her mass immigration to Turkey took place during the Bosnian war. The figures about their immigration are not so clear, yet, According to Acma (2008), more than 1,6 million immigrants settled in Turkey between 1923 and 1990s and more than 90 percent of all immigrants arrived from the Balkan countries. Since Bosnians shared the historical and cultural heritage of the Ottoman Empire and are regarded as close to the Turkish cultural identity, they are seen as natural members of Turkish nation by both parties (Cavusoglu, 2007; Ulker, 2007; Hajdarpasic, 2008) and their immigration actively encouraged by the state (Kirisci, 2007). Their immigration to Turkey was conceived as a factor strengthening the cohesion and homogeneity of Turkish nation. In order to facilitate assimilation on the basis of Turkish language and culture, Balkan immigrants were granted full citizenship upon their arrival in Turkey and settled among Turkish speaking population in Marmara and Aegean regions and to a lesser extent in central Anatolia. The state provided resources, land and employment opportunities for immigrants until early 1970s (Kirisci, 2007; Acma, 2008; Ulker, 2007). Since their immigration mostly took place based on the rules set by the public authority, they were usually not considered by natives as "a major problem" (Erder, 2006). In a study, Bosnian immigrants are found to embrace Ottoman-Turkish ethnic identity and heritage more that Turks do (Alparslan, 2006). Despite that, immigrants' life was not without problems (Cetin, 2008). For instance, some of those immigrants who are initially settled in rural areas moved to urban areas due to acceptance and unemployment problems (Doganay, 1996).

Embracing a diverse population with various ethnic and religious backgrounds, Izmir, Turkey's third most populous city, is best known for its westernized consumptionscape in Turkey. As an exemplar of westernized Turkish consumer culture, the cultural context of Izmir provides a rich source for data collection. The data were collected in Çamdibi, a neighborhood where 5850 Bosnians accommodate. They can be defined as a close-knit community. A questionnaire survey has been conducted with 382 Bosnians in 2009. The questionnaire involves questions about acculturation, consumer culture, immigration and demographics. Questions about acculturation, cultural identification and consumer culture are developed by researchers based on personal interviews with fifteen Bosnian immigrants, ten managers of Balkan, Bosnian specifically, immigrant associations, seven mukhtars (elected heads of the Bosnian neighborhoods) in Çamdibi and the honorary consulate of Bosnia-Herzegovina in Izmir and based on literature 
(e.g. Jun, Ball and Gentry, 1993; Penaloza, 1994; Ger et al., 1998; Ustuner and Holt, 2007; Ustuner et al., 2007; Berry, 1997; Berry et al., 2006; Wilson, 2007; Tari et al., 2008; Sandikci et al., 2006). Acculturation items include statements such as"I think we have maintained our original culture","I prefer being friends with both Turks and Bosnians","I prefer our own cusine to the local cuisine", "I want to live in harmony with Turkish culture while maintaining ours", "I raise my children according to both our own and Turkish culture", "I can easily integrate into the host culture", "I believe that membership in Bosnian associations is important". Internal consistency reliability coefficient Cronbach alpha is 0,756. Items about encounters with local consumer culture include statements such as "Through consumption of some brands, people try to convey meanings of prestige and modernity", "I like to indulge in luxury", "Having a credit card is a matter of an esteemed social status", "Immigrants in the neighborhood prefer branded goods in order to communicate their social status", " would like to live just like celebrities I see in movies "',' prefer products/brands that suit my lifestyle", "I purchase products only when really needed", "I prefer buying foreign and global brands", "I am attracted to a western consumption culture" and "Shopping centers are indispensable in my life". Internal consistency reliability coefficient Cronbach alpha is 0,865.

Since race of the Bosnian immigrants in Turkey is varied and not well-known by the respondents owing to the fact that both ethnic groups mingled during

Table 1: Demographic and Socio-Economic Characteristics of the Sample

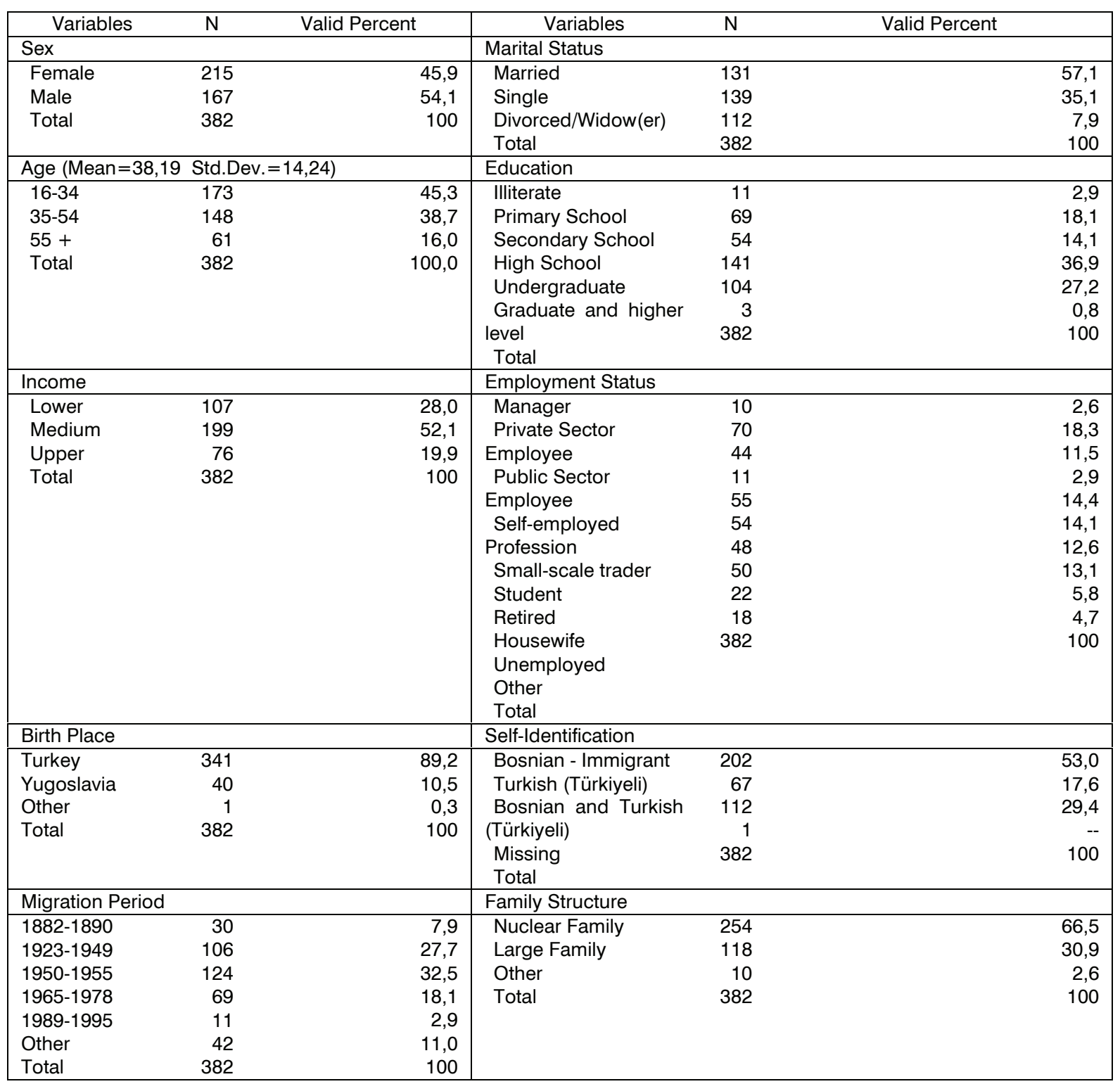


the Ottoman Empire dynasty in Bosnia, questions about race are not included in the questionnaire. Instead, a nominal scale of ethnic self-identification with three categories is included. Categories include Bosnian immigrant, Turkish (Turkiyeli), Bosnian and Turkish (Turkiyeli). The term "Turkiyeli" is used instead of Turk with the intention of avoiding the ambivalences about race. After a pilot test, the questionnaire was revised so that inapplicable questions and ambiguous wording could be avoided.

Majority of the respondents are male and married (Table 1). Majority identify themselves Bosnian immigrants (53\%), whereas others identify themselves as Turkiyeli (17,6\%), and Bosnian and Turkiyeli $(29,4 \%)$. Most of the respondents migrated during periods 1923-1949 and 1950-1955. Political tensions between Turkish Republic and Kingdom of Serbs, Croats and Slovenes (and soon after Yugoslavia), in addition to economical problems, were the main causes of the immigration movement in 1923-1949 (Oksuz, 2006). Soon after the Balkan Pact of 1953 signed by Greece, Turkey, and Yugoslavia, Yugoslavia granted permission to free movement of Bosnians across borders. Thus, thousands of Bosnians migrated to Turkey. Furthermore, most of the respondents are born in Turkey. Hence, it can be proposed that the sample mostly include immigrants who are not first-generation immigrants.

\section{FINDINGS}

Findings of one sample t-tests about the respondents' involvement and acculturation in consumer culture experienced in Izmir reveal that Bosnian immigrants share only some of consumer cultural values. Although, in general, Bosnian immigrants seem to be aware of the consumer cultural values, they, behaviorally and attitudinally, separate themselves from the host consumer culture. This may be because of their tendency to maintain and defend their own culture from consumer culture experienced in Izmir. They, for instance, agree that one can express and negotiate his/ her personality $(\mathrm{t}(381)=4,73 \mathrm{p}<, 05)$ through consumption. They also agree that products and brands can be used as means to construct and demonstrate one's lifestyle $(\mathrm{t}(381)=18,99 \mathrm{p}<, 05)$ and through consumption of some brands, people try to convey messages of prestige and modernity $(t(381)=5,70 p<, 05$. On the other hand, they do not agree that shopping centers are indispensable in their lives $(t(381)=5,76 p<, 05)$. They also do not prefer brands on the basis of the brand's performance in providing them popularity and an esteemed standing in society $(t(381)=-7,81 p<, 05)$. They do not believe that immigrants in their neighborhood prefer branded goods in order to communicate their social status $(t(381)=-3,23 p<, 05)$. They do not prefer foreign branded goods specifically $(t(381)=-4,59$ $\mathrm{p}<, 05)$ and indulge in luxury $(\mathrm{t}(381)=-7,71 \mathrm{p}<, 05)$, and are not attracted to a western consumption culture $(\mathrm{t}(381)=-7,92 \mathrm{p}<, 05)$. Instead, they purchase products only when really needed $(t(381)=25,67 p<, 05)$, try to live up to their income $(t(381)=23,56 p<0,05)$, and prefer products/brands that suit their lifestyle $(t(381)=18,99 p<, 05)$. They rely on their family for advice in their consumption decisions $(t(381)=3,52 p<, 05)$, not on commercials $(t(381)=-3,23 p<, 05)$ or on other referents, such as celebrities that are marketed as role models in consumption society $(t(381)=-9,99 p<, 05)$. Furthermore, they are neither deeply engaged in popular media and TV shows that are intensely used by companies as means of product placement $(\mathrm{t}(381)=-$ $3,11 \mathrm{p}<, 05)$ nor use Internet for shopping experience $(t(381)=-11,35 p<, 05)$.

Respondents' tendency to maintain their home culture reveals itself in some other findings. The findings show that they maintain their home culture values and customs $(t(381)=10,08 p<, 05)$ and they place importance on being a member of Bosnian associations and groups in Turkey $(\mathrm{t}(381)=6,69 \mathrm{p}<, 05)$. Despite that, it is not possible to suggest that their tendency to maintain their cultural heritage is extremely strong. They, in general, do not profoundly tend to use products/brands that express their Bosnian identity and have large numbers of belongings that relate to their past and Bosnian culture. Respondents, mostly, try to integrate into general Turkish culture both attitudinally and behaviorally while maintaining their home culture and trying to avoid the consumer culture. They believe that they were not subjected to ethnic discrimination $(t(381)=9,19 p<, 05)$ and try to integrate into the host culture $(t(381)=8,32 p<, 05)$. For instance they prefer being friends with both Turks and Bosnians $(t(381)=10,69 p<, 05)$, raise their children according to both their own and Turkish culture $(\mathrm{t}(381)=20,82$ $\mathrm{p}<, 05)$, live in harmony with Turkish culture while maintaining theirs $(t(381)=19,99 p<, 05)$, and enjoy both Turkish media and media of their origin $(t(381)=8,32$ $p<, 05)$. These findings also show that Bosnian immigrants have an integrative attitude toward Turkish culture. It could be because of the mutual history of Bosnians and Turks under the Ottoman Empire. However, they try to shield their community from consumer culture experienced in Izmir, as well. 


\subsection{Differences in Attitudes and Behaviors Based on Ethnic Self-Identification}

The findings show differences between respondents who identify themselves as immigrants and respondents who do not identify themselves as immigrants. Respondents who identify themselves as immigrants are comparably more conservative than others. Their tendency to maintain and defend their own culture from consumer culture experienced in Iz- mir is significantly higher than the respondents who do not identify themselves as immigrants. For instance, they believe that immigrants in their neighborhood prefer branded goods in order to show-off ( $\mathrm{t}=2,055$ $d f=344 p<0,05)$. and to communicate their social status $(t=2,019 \mathrm{df}=381 \mathrm{p}<0,05)$ comparably stronger than the respondents who do not identify themselves as immigrants. Their tendency to purchase products only when really needed $(t=3,003 d f=381 p<0,05)$, try

Table 2: Differences in Attitudes and Behaviors Based on Ethnic Self-Identification

\begin{tabular}{|c|c|c|c|c|}
\hline & & $\mathrm{N}$ & Mean & Std. Dev. \\
\hline \multirow{4}{*}{$\begin{array}{l}\text { I try to live up to my income } \\
F=3,581 \mathrm{df}=2 / 378 p=, 029\end{array}$} & Bosnian & 202 & 4,30 & ,983 \\
\hline & Turkish & 67 & 3,93 & 1,020 \\
\hline & Both & 112 & 4,22 & ,975 \\
\hline & Total & 381 & 4,21 & ,994 \\
\hline \multirow{4}{*}{$\begin{array}{l}\text { I prefer buying foreign and global brands. } \\
F=4,083 \mathrm{df}=2 / 378 \mathrm{p}=, 018\end{array}$} & Bosnian & 202 & 2,54 & 1,289 \\
\hline & Turkish & 67 & 2,79 & 1,052 \\
\hline & Both & 112 & 2,95 & 1,251 \\
\hline & Total & 381 & 2,70 & 1,250 \\
\hline \multirow{4}{*}{$\begin{array}{l}\text { Having a credit card is a matter of an esteemed social status. } \\
F=11,220 \mathrm{df}=2 / 378 p=, 000\end{array}$} & Bosnian & 202 & 2,09 & 1,105 \\
\hline & Turkish & 67 & 2,87 & 1,205 \\
\hline & Both & 112 & 2,39 & 1,269 \\
\hline & Total & 381 & 2,32 & 1,204 \\
\hline \multirow{4}{*}{$\begin{array}{l}\text { I have large numbers of belongings that remind me my Bosnian } \\
\text { identity and heritage. } \\
F=3,792 \mathrm{df}=2 / 378 \mathrm{p}=, 023\end{array}$} & Bosnian & 202 & 3,16 & 1,158 \\
\hline & Turkish & 67 & 2,75 & 1,119 \\
\hline & Both & 112 & 3,17 & 1,090 \\
\hline & Total & 381 & 3,09 & 1,140 \\
\hline \multirow{4}{*}{$\begin{array}{l}\text { Through consumption of some brands, people try to convey } \\
\text { meanings of prestige and modernity } \\
F=4,266 \mathrm{df}=2 / 378 p=, 015\end{array}$} & Bosnian & 202 & 3,27 & 1,218 \\
\hline & Turkish & 67 & 3,10 & 1,046 \\
\hline & Both & 112 & 3,58 & 1,045 \\
\hline & Total & 381 & 3,33 & 1,150 \\
\hline \multirow{4}{*}{$\begin{array}{l}\text { I would like to live just like celebrities I see in movies } \\
F=6,749 \mathrm{df}=2 / 378 p=, 001\end{array}$} & Bosnian & 202 & 2,18 & 1,149 \\
\hline & Turkish & 67 & 2,55 & 1,145 \\
\hline & Both & 112 & 2,65 & 1,221 \\
\hline & Total & 381 & 2,38 & 1,188 \\
\hline \multirow{4}{*}{$\begin{array}{l}\text { I usually use products/brands that express my Bosnian identity. } \\
F=8,794 \mathrm{df}=2 / 378 \mathrm{p}=, 000\end{array}$} & Bosnian & 202 & 2,92 & 1,121 \\
\hline & Turkish & 67 & 2,61 & ,920 \\
\hline & Both & 112 & 3,30 & 1,177 \\
\hline & Total & 381 & 2,98 & 1,128 \\
\hline \multirow{4}{*}{$\begin{array}{l}\text { I prefer being friends with both Turks and Bosnians } \\
F=3,603 d f=2 / 378 p=, 028\end{array}$} & Bosnian & 202 & 3,80 & 1,189 \\
\hline & Turkish & 67 & 3,34 & 1,188 \\
\hline & Both & 112 & 3,66 & 1,277 \\
\hline & Total & 381 & 3,68 & 1,224 \\
\hline \multirow{4}{*}{$\begin{array}{l}\text { I raise my children according to both our own and Turkish culture } \\
F=9,468 d f=2 / 378 p=, 000\end{array}$} & Bosnian & 202 & 4,19 & ,949 \\
\hline & Turkish & 67 & 3,60 & 1,060 \\
\hline & Both & 112 & 4,07 & ,937 \\
\hline & Total & 381 & 4,05 &, 987 \\
\hline \multirow{4}{*}{$\begin{array}{l}\text { I think we have maintained our original culture. } \\
F=12,913 \mathrm{df}=2 / 378 p=, 000\end{array}$} & Bosnian & 202 & 3,63 & 1,207 \\
\hline & Turkish & 67 & 3,03 & 1,000 \\
\hline & Both & 112 & 3,91 & 1,045 \\
\hline & Total & 381 & 3,61 & 1,162 \\
\hline \multirow{4}{*}{$\begin{array}{l}\text { I can easily integrate into the host culture } \\
F=8,699 \mathrm{df}=2 / 378 p=, 000\end{array}$} & Bosnian & 202 & 3,59 & 1,157 \\
\hline & Turkish & 67 & 2,97 & 1,218 \\
\hline & Both & 112 & 3,63 & 1,040 \\
\hline & Total & 381 & 3,49 & 1,158 \\
\hline \multirow{4}{*}{$\begin{array}{l}\text { I prefer our own cusine to the local cuisine. } \\
F=6,666 \mathrm{df}=2 / 378 p=, 001\end{array}$} & Bosnian & 202 & 3,30 & 1,193 \\
\hline & Turkish & 67 & 3,04 & 1,173 \\
\hline & Both & 112 & 3,68 & 1,187 \\
\hline & Total & 381 & 3,36 & 1,206 \\
\hline
\end{tabular}

*1 = strongly disagree, $5=$ stongly agree ${ }^{*}$ Insignificant results are not reported. 
to live up to their income $(t=2,138 d f=381 p<0,05)$, have large numbers of belongings that remind Bosnian identity and heritage $(t=3,157 \mathrm{df}=381 \mathrm{p}<0,05)$ and their belief that they have maintained their original culture $(t=3,745 d f=381 p<0,05)$ are also stronger. Nevertheless, this tendency does not indicate separation or marginalization.

Those who identify themselves as Bosnians appear to be more conservative than others. Their tendency to maintain and defend their own culture from consumer culture experienced in Izmir is significantly higher than others (Table 2). Yet, this tendency does not indicate separation. This findings support the hypothesis that immigrants who have stronger ethnic selfidentification are more likely to maintain their cultural heritage. Those who identify themselves Turkish have adopted consumer cultural values experienced in Izmir and tend to move away from their origins at a higher degree than others. Those who identify themselves Bosnian and Turkish at the same time reveal interesting attitudes and behaviors. Although they seem to have integrated into the Turkish consumer culture, they also maintain their Bosnian culture and identity. These respondents seem to have a hybrid identity (e.g. Ger et al., 1998) that can be formed through interaction of both cultures and identities. These findings may also indicate fluid and diverse nature of consumer ethnic identities (e.g. Cherrier et al., 2009).

\subsection{Findings Related to Cultural Heritage, Cultural Pride, Ethnic Discrimination and the Length of Stay}

Respondents who have maintained their cultural heritage are more likely to maintain their original culture. There are positive correlations between possessing large numbers of belongings that relate to the ethnic identity and heritage and disliking Turkish consumer culture $(r=, 17 p<, 05)$, living up to income $(r=, 16$ $p<, 05)$, and purchasing products only when really needed $(r=, 52 p<, 05)$. Yet, there is no significant correlation between acculturation to consumer culture and maintaining cultural heritage by, for instance, possessing large numbers of belongings that relate to the ethnic identity and heritage.

Findings also support the hypothesis that the longer immigrants are in the new culture, the more they are acculturated (e.g. Berry et al, 2006). Respondents who identify themselves as Turkish have been significantly longer in Turkey than those who identify themselves as Bosnian and Bosnian and Turkish $(F(2 / 378)=10,47 p<, 05)$. Although it is found that that the longer respondents are in the Turkish consumer culture, the more they develop negative attitudes to- ward consumer culture experienced in Izmir, the age of the respondents seem to moderate this relationship. When the age is considered as a control variable, this finding becomes insignificant. Another interesting finding is that although respondents who prefer contact both Bosnian and Turkish peers have more integrative attitudes, they have maintained their original culture $(r=, 24 p<, 05)$ yet not fully integrated into consumer culture experienced in Izmir. Their integrative attitudes are reveal themselves in terms of their willingness to raise their children according to both home and host culture $(r=, 31 \mathrm{p}<, 05)$, live in harmony with Turkish culture while maintaining theirs $(r=, 32$ $p<, 05$ ), and enjoy both Turkish media and media of their origin $(r=, 27 p<, 05)$. The more they contact Bosnians in addition to Turkish peers, the less they assign credit cards a meaning of social status $(r=-, 14 p<, 05)$ and the more they contend with their income $(r=, 26$ $\mathrm{p}<, 05)$ and buy products when needed $(r=, 22 \mathrm{p}<, 05)$.

Furthermore, immigrants' frequency of contact with their home country also influences acculturation. As expected, the tendency to maintain the original culture is stronger among respondents who visit Bosnia and Herzegovina more frequently than others. For instance, when compared to infrequent visitors, frequent visitors have more belongings that relate to the Bosnian identity and heritage $(F(5 / 376)=10,36$ $p<, 05)$, use products/brands that express their Bosnian identity $(F(5 / 376)=6,23 p<, 05)$, prefer their ethnic food at home more $(F(5 / 376)=3,59 p<, 05)$, rely on their family for advice in their consumption choices $(F(5 / 376)=4,82 p<, 05)$, and stronger tend place importance on their membership in Bosnian associations $(F(5 / 376)=3,82 p<, 05)$. They do not believe that they have maintained their original culture as infrequent visitors do $(F(5 / 376)=4,64 p<, 05)$.

Respondents, generally, do not perceive ethnic discrimination and there are no significant differences between respondents who identify themselves as Turkish, Bosnian and Bosnian and Turkish $(F(2 / 378)=1,07$ $p>, 05)$ in terms of perceived ethnic-discrimination.

\subsection{Findings Related to Demographical Factors}

Findings about the relationship between gender and immigrants' acculturation differ from the literature. Male respondents' beliefs that they have maintained their culture are stronger than females'. Men tend to join Bosnian associations ( $t(344)=-2,63 p<, 05)$, possess large numbers of belongings that relate to their Bosnian identity and heritage $(t(380)=-2,54 p<, 05)$, and believe that immigrants in their neighborhood prefer branded goods in order to show-off $(t(380)=-$ 
Table 3: Correlations Between Age and Some Acculturation Statements $(\mathrm{N}=382)$

\begin{tabular}{|l|l|l|}
\hline & $\begin{array}{l}\text { Pearson } \\
\text { Correlation }\end{array}$ & Sig. \\
\hline $\begin{array}{l}\text { Shopping centers are indispensible in } \\
\text { my life }\end{array}$ & $-0,215$ & 0,000 \\
\hline $\begin{array}{l}\text { I prefer brands on the basis of the } \\
\text { brand's performance in providing } \\
\text { popularity and an esteemed standing } \\
\text { in society }\end{array}$ & $-0,211$ & 0,000 \\
\hline $\begin{array}{l}\text { Keeping track of fashion trends is } \\
\text { important for me }\end{array}$ & $-0,294$ & 0,000 \\
\hline $\begin{array}{l}\text { I prefer buying foreign and global } \\
\text { brands. }\end{array}$ & $-0,333$ & 0,000 \\
\hline $\begin{array}{l}\text { I can express and negotiate my } \\
\text { personality through consumption of } \\
\text { brands }\end{array}$ & $-0,220$ & 0,000 \\
\hline I like to indulge in luxury & $-0,199$ & 0,000 \\
\hline $\begin{array}{l}\text { Through consumption of some } \\
\text { brands, people try to convey } \\
\text { meanings of prestige and modernity }\end{array}$ & $-0,251$ & 0,000 \\
\hline $\begin{array}{l}\text { I would like to live just like celebrities I } \\
\text { see in movies }\end{array}$ & $-0,177$ & 0,001 \\
\hline $\begin{array}{l}\text { I can easily integrate into the host } \\
\text { culture }\end{array}$ & $-0,143$ & 0,005 \\
\hline
\end{tabular}

*Insignificant results are not reported.

$1,98 p<, 05)$ stronger than women, whereas women agree to the statements "shopping centers are indispensible in my life" $(t(380)=2,60 p<, 05)$ and "through consumption of some brands, people try to convey messages of prestige and modern image" $(\mathrm{t}(380)=2,90$ $p<, 05)$ stronger than men.

Correlation analyses demonstrate the younger the immigrants the more they are acculturated to consumer culture experienced in Izmir (Table 3). Besides, there are no significant relation between age and the statements about maintaining the home culture. The respondents, in general, try to maintain their original culture. The reason may rest on respondents' heightened ethnic sensitivity due to the genocide Bosnians suffered during Bosnian war between 1992 and 1995.

Findings reveal that the respondents who are born in Turkey are more integrated into Turkish consumer culture, whereas respondents who are born in former Yugoslavia believe that they have maintained their original culture stronger than others, for instance they possess large numbers of belongings that relate to their Bosnian identity and heritage. Yet, they also try to integrate into the Turkish community as well (Table 4). Similar to the suggestions in the literature, the findings also suggest that the respondents who were not born in Turkey and immigrated at a later age tend to maintain their original culture while integrating into the Turkish community. They believe that they have maintained their original culture $(r=, 37 p<, 05)$, raise their children according to both home and host culture $(r=, 36 p<, 05)$, live in harmony with Turkish culture while maintaining theirs $(r=, 26 p<, 05)$, and enjoy both Turkish media and media of their origin $(r=, 45 p<, 05)$.

The more affluent the respondents are, the stronger they believe that they can easily integrate into the host culture $(r=, 12 p<, 05)$ and the less they believe they are subjected to ethnic discrimination $(r=-, 17$ $p<, 05)$. Respondents who identify themselves as Turkish and Bosnian and Turkish have also more income than the respondents who identify themselves as Bosnians $(F(2 / 378)=3,93 p<, 05)$. Affluent respondents are also more acculturated to Turkish consumer culture. The more affluent the respondents are, the stronger they believe that they can express and negotiate their personality through consumption of brands $(r=, 11$ $\mathrm{p}<, 05$ ).

The higher educated respondents are more acculturated to Turkish consumer culture. When compared to lower educated respondents, higher educated respondents stronger believe that they can express and negotiate their personality through consumption of brands $(F(5 / 376)=3,75 p<, 05)$, prefer brands on the basis of the brand's performance in providing popularity and an esteemed standing in society $(F(5 / 376)=3,96 p<, 05)$, stronger believe that through consumption of some brands, people try to convey messages of prestige and modernity $(F(5 / 376)=2,55$ $p<, 05)$, like to indulge in luxury more $(F(5 / 376)=2,61$ $p<, 05)$, place more importance on keeping track of fashion trends $(F(5 / 376)=8,14 p<, 05)$ and stronger believe that they can easily integrate into the host culture $(F(5 / 376)=4,19 p<, 05)$.

Furthermore, single respondents are more acculturated to Turkish consumer culture. When compared to married respondents, single respondents stronger believe that they can express and negotiate their personality through consumption of brands $(t(380)=-2,71$ $p<, 05)$, prefer brands on the basis of the brand's performance in providing popularity and an esteemed standing in society $(\mathrm{t}(380)=-3,75 \mathrm{p}<, 05)$, stronger believe that through consumption of some brands, people try to convey messages of prestige and modernity $(t(380)=-3,76 p<, 05)$, like to indulge in luxury more $(\mathrm{t}(380)=-2,69 \mathrm{p}<, 05)$, place more importance on keeping track of fashion trends $(t(380)=-3,37 p<, 05)$ and stronger believe that they can easily integrate into the host culture $(F(5 / 376)=4,19 p<, 05)$. They also tend to choose foreign and global brands more than others and rely on referents other than their community and family members, such as celebrities that are marketed as role models in consumption society $(\mathrm{t}(338)=-2,07$ $p<, 05)$. 
Table 4: Differences in Attitudes and Behaviors According to Birth Place

\begin{tabular}{|c|c|c|c|c|}
\hline & Birth Place & $\mathrm{N}$ & Mean & Std.Dev. \\
\hline \multirow{2}{*}{$\begin{array}{l}\text { Immigrants in my neighborhood prefer branded goods in order to show-off }(t=2,962 \\
d f=51,599 p<0,05)\end{array}$} & Turkey & 341 & 3,108 & 1,434 \\
\hline & Yugoslavia & 40 & 2,475 & 1,261 \\
\hline \multirow{2}{*}{$\begin{array}{l}\text { Shopping centers are indispensible in my life } \\
(\mathrm{t}=3,249 \mathrm{df}=50,598 \mathrm{p}<0,05)\end{array}$} & Turkey & 341 & 2,701 & 1,248 \\
\hline & Yugoslavia & 40 & 2,075 & 1,141 \\
\hline \multirow{2}{*}{$\begin{array}{l}\text { I prefer brands on the basis of the brand's performance in providing popularity and an } \\
\text { esteemed standing in society } \\
(\mathrm{t}=3,637 \mathrm{df}=51,403 \mathrm{p}<0,05)\end{array}$} & Turkey & 341 & 2,607 & 1,157 \\
\hline & Yugoslavia & 40 & 1,975 & 1,025 \\
\hline \multirow{2}{*}{$\begin{array}{l}\text { Keeping track of fashion trends is important for me } \\
(\mathrm{t}=3,783 \mathrm{df}=379 \mathrm{p}<0,05)\end{array}$} & Turkey & 341 & 2,965 & 1,227 \\
\hline & Yugoslavia & 40 & 2,175 & 1,430 \\
\hline \multirow{2}{*}{$\begin{array}{l}\text { I try to live up to my income } \\
(\mathrm{t}=-1,981 \mathrm{df}=379 \mathrm{p}<0,05)\end{array}$} & Turkey & 341 & 4,170 & 0,994 \\
\hline & Yugoslavia & 40 & 4,500 & 1,013 \\
\hline \multirow{2}{*}{$\begin{array}{l}\text { I prefer buying foreign and global brands. } \\
(\mathrm{t}=3,689 \mathrm{df}=379 \mathrm{p}<0,05)\end{array}$} & Turkey & 341 & 2,783 & 1,220 \\
\hline & Yugoslavia & 40 & 2,025 & 1,310 \\
\hline \multirow{2}{*}{$\begin{array}{l}\text { I purchase products only when really needed } \\
(\mathrm{t}=-2,345 \mathrm{df}=379 \mathrm{p}<0,05)\end{array}$} & Turkey & 341 & 4,205 & 0,960 \\
\hline & Yugoslavia & 40 & 4,575 & 0,781 \\
\hline \multirow{2}{*}{$\begin{array}{l}\text { I can express and negotiate my personality through consumption of brands }(t=2,072 \\
d f=379 p<0,05)\end{array}$} & Turkey & 341 & 3,349 & 1,212 \\
\hline & Yugoslavia & 40 & 2,925 & 1,328 \\
\hline \multirow{2}{*}{$\begin{array}{l}\text { I like to indulge in luxury } \\
(\mathrm{t}=2,224 \mathrm{df}=379 \mathrm{p}<0,05)\end{array}$} & Turkey & 341 & 2,572 & 1,188 \\
\hline & Yugoslavia & 40 & 2,125 & 1,3241 \\
\hline \multirow{2}{*}{$\begin{array}{l}\text { I rely on my family in my consumption decisions } \\
(\mathrm{t}=3,125 \mathrm{df}=51,247 \mathrm{p}<0,05)\end{array}$} & Turkey & 341 & 3,314 & 1,354 \\
\hline & Yugoslavia & 40 & 2,675 & 1,207 \\
\hline \multirow{2}{*}{$\begin{array}{l}\text { Having a credit card is a matter of an esteemed social status. }(t=5,618 \mathrm{df}=59,802 \\
p<0,05)\end{array}$} & Turkey & 341 & 2,411 & 1,213 \\
\hline & Yugoslavia & 40 & 1,575 & 0,844 \\
\hline \multirow{2}{*}{$\begin{array}{l}\text { Immigrants in their neighborhood prefer branded goods in order to communicate their } \\
\text { social status }(t=4,152 \mathrm{df}=51,661 \mathrm{p}<0,05)\end{array}$} & Turkey & 341 & 2,877 & 1,216 \\
\hline & Yugoslavia & 40 & 2,125 & 1,067 \\
\hline \multirow{2}{*}{$\begin{array}{l}\text { I have large numbers of belongings that remind me my Bosnian identity and heritage. }(\mathrm{t}=- \\
2,325 \mathrm{df}=44,596 \mathrm{p}<0,05)\end{array}$} & Turkey & 341 & 3,038 & 1,088 \\
\hline & Yugoslavia & 40 & 3,575 & 1,412 \\
\hline \multirow{2}{*}{$\begin{array}{l}\text { Through consumption of some brands, people try to convey meanings of prestige and } \\
\text { modernity }(t=2,129 \mathrm{df}=45,989 \mathrm{p}<0,05)\end{array}$} & Turkey & 341 & 3,384 & 1,123 \\
\hline & Yugoslavia & 40 & 2,925 & 1,309 \\
\hline \multirow{2}{*}{$\begin{array}{l}\text { I would like to live just like celebrities I see in movies } \\
(\mathrm{t}=2,935 \mathrm{df}=379 \mathrm{p}<0,05)\end{array}$} & Turkey & 341 & 2,455 & 1,181 \\
\hline & Yugoslavia & 40 & 1,875 & 1,181 \\
\hline \multirow{2}{*}{$\begin{array}{l}\text { I prefer being friends with both Turks and Bosnians } \\
(\mathrm{t}=-2,448 \mathrm{df}=379 \mathrm{p}<0,05)\end{array}$} & Turkey & 341 & 3,628 & 1,163 \\
\hline & Yugoslavia & 40 & 4,125 & 1,604 \\
\hline \multirow{2}{*}{$\begin{array}{l}\text { I raise my children according to both our own and Turkish culture }(t=-2,538 d f=379 \\
p<0,05)\end{array}$} & Turkey & 341 & 4,015 & 0,987 \\
\hline & Yugoslavia & 40 & 4,425 & 0,781 \\
\hline \multirow{2}{*}{$\begin{array}{l}\text { I want to live in harmony with Turkish culture while maintaining ours. }(t=-3,069 d f=379 \\
p<0,05)\end{array}$} & Turkey & 341 & 3,991 & 1,016 \\
\hline & Yugoslavia & 40 & 4,500 & 0,751 \\
\hline \multirow{2}{*}{$\begin{array}{l}\text { I think we have maintained our originalculture. } \\
(\mathrm{t}=-3,905 \mathrm{df}=379 \mathrm{p}<0,05)\end{array}$} & Turkey & 341 & 3,531 & 1,149 \\
\hline & Yugoslavia & 40 & 4,275 & 1,062 \\
\hline \multirow{2}{*}{$\begin{array}{l}\text { I enjoy both Turkish and Bosnian media } \\
(\mathrm{t}=-4,009 \mathrm{df}=49,66 \mathrm{p}<0,05)\end{array}$} & Turkey & 341 & 3,337 & 1,151 \\
\hline & Yugoslavia & 40 & 4,075 & 1,095 \\
\hline
\end{tabular}

*1 = strongly disagree, $5=$ stongly agree $* *$ Insignificant results are not reported.

\section{CONCLUSIONS}

Past and ongoing ethnic and religious conflicts at home are suggested to institute nationalist narratives and heighten interest in ethnic roots (Lieberman, 2006) and a sense of ethnic self-defense whether immigrants face real discrimination in host country or not. As a result of this, different patterns of consumer acculturation might be observed. The present study aims to contribute to the existing literature by studying consumer acculturation of Bosnian immigrants who had or needed to migrate because of negative political and religious environment, in addition to socio-economical problems, in their home country. During the history, Bosnians faced frequent wars, tensions and several political instable periods, resulting in several mass immigration movements. The ethnic cleansing attempts during the Bosnian war, in recent history, are sugges- ted to arouse in a stronger European Muslim identity among Bosnians (Makrides, 2007).

Findings reveal that Bosnian immigrants have integrative attitudes toward Turkish culture while maintaining their original culture. Their integrative attitudes may stem from the shared history of Bosnians and Turks under the Ottoman Empire. Since they, in general, do not believe that they are subjected to ethnicdiscrimination, they may have developed integrative attitudes as well. Bosnian immigrants also try to maintain their original culture. Despite that, it is not possible to suggest that their tendency to maintain their cultural heritage is extremely strong. It is possible suggest that despite the heightened ethnic sensitivity due to the Bosnian war between 1992-1995, they do not try to separate themselves from Turkish culture. This may indicate that social and historical factors are important 
agents in the acculturation process. During the shared history of Bosnians and Turks under the Ottoman Empire, both cultures have developed shared understandings and some degree of collective consciousness based on a belief in shared tradition, history and religion. Castles and Davidson (2000) remarked that if a group is marginalized by strongly negative otherdefinitions, it may emphasize its cultural identity as a source of resistance, i.e. they develop a stronger ethnic self-identification and resist to discrimination and alienation. In the current case, Bosnian immigrants' strong self-identification rest not on perceived/real discrimination, but on ongoing turbulence in their home country. Hence, it can be suggested the other-definition is not negative, despite the fact that Bosnian immigrants' ethnic self-identification and sensitivity appears to be strong. Thus, we can propose that Bosnian immigrants have an integrative attitude toward Turkish culture while maintaining their original culture.

Yet, it can also be proposed that they try to shield their community from consumer culture experienced in Izmir. For instance, it is found that although respondents who prefer contact with both Bosnian and Turkish peers have more integrative attitudes, they have maintained their original culture, yet not fully integrated into consumer culture experienced in Izmir. Increased ethnic sensitivity due to the war conditions at home and their tendency to maintain their original culture influences their acculturation tendency to consumer culture experienced in Izmir.

Findings reveal that the immigrants who have stronger ethnic self-identification are more likely to maintain their cultural heritage. Those who identify themselves as Bosnians appear to be more conservative than others. Yet, this tendency does not indicate separation. Those who identify themselves Turkish have adopted consumer cultural values experienced in Izmir and tend to move away from their origins more than others. Those who identify themselves Bosnian and Turkish at the same time reveal interesting attitudes and behaviors. Although they seem to have integrated into the Turkish consumer culture, they also maintain their Bosnian culture and identity. These respondents seem to have a hybrid identity (e.g. Ger et al., 1998; Askegaard et al., 2005) that can be formed through interaction of both cultures and identities. These findings may also indicate fluid and diverse nature of consumer ethnic identities (Cherrier et al., 2009).

The findings about how demographics variables affect consumer acculturation are mostly in line with the literature. Younger, single, more affluent, and higher educated immigrants have learned the Turkish consumer culture faster than older, married, less affluent, and lower educated immigrants. However, we could not find any significant relation between age and the statements about maintaining the home culture. The respondents, in general, try to maintain their original culture. Furthermore, contrary to the suggestions in the literature, men have maintained their original culture stronger than women, whereas women are more acculturated to the consumer culture. The reason why these findings are inconsistent with the literature may also rest on heightened ethnic sensitivity and stong ethnic self-identification due to the ongoing turbulence in their home country.

Some other findings are consistent with the literature. Immigrants who have maintained their cultural heritage are more likely to maintain their original culture. Furthermore, it is found that the longer immigrants are in the host culture, the more they are acculturated. Respondents who identify themselves as Turkish have been significantly longer in Turkey than those who identify themselves as Bosnian and Bosnian and Turkish. Besides, immigrants' frequency of contact with their home country also influences acculturation. The tendency to maintain the original culture is stronger among respondents who visit Bosnia-Herzegovina more frequently than others. Additionally, there are significant relationships between monitoring Bosnian media next to Turkish media and statements that relate to original culture maintenance while trying to integrate into Turkish society.

Findings of the present study may be seen as a contribution to the literature. First, it is demonstrated that acculturation of consumers who had or needed to migrate because of a negative ethnic and religious environment, as well as socio-economical problems, in their home country may have different patterns. Heightened ethnic self-identification, even in the absence of ethnic-discrimination in the host country, may withhold immigrants in their acculturation process. Second, it is also shown that the shared history of Bosnians and Turks under the Ottoman Empire, and shared tradition and religion may be drivers of the acculturation process of Bosnians in Turkey.

This study is not without limitations; first, the operationalization of the variables does not allow exploring change in identity projects of Bosnian immigrants in depth. Additionally, cross-sectional quantitative data did not allow exploring the acculturation process as well. A future qualitative study may help to explore their acculturation process and identity projects. Moreover, the sample might not represent the general Bosnian immigrant population in Turkey. Yet, this study can be seen as a preliminary effort to understand acculturation of Bosnian immigrants in Turkey. 


\section{END NOTES}

Previous version of the paper was presented during IMDA 19th World Business Congress, 2010.

\section{REFERENCES}

Acma, B. (2008) "Economic Consequences of International Migration: As a Case Study Turkey", WIDER Conference on Poverty, International Migration and Asylum (27-28 September 2002), http://website1.wider.unu.edu/conference/ conference-2002-3/conference $\% 20$ papers/acma.pdf, (10.03.2010).

Alparslan, S. (2006) Bosna'da Turk Kulturunun İleri, Genelkurmay ATASE ve Denetleme Baskanlıgı Yayınları, Ankara: Genelkurmay Basım Evi.

Anderson, Laurel (2008) "Dynamic Inbetweeness: Ethnic Consumer Dialogue Zones", Lee \& Soman (eds.), Duluth, MN: Association for Consumer Research Advances in Consumer Research, 35: 31-32.

Arnould, E. J. and Thompson, C. J (2005) "Consumer Culture Theory (CCT): Twenty Years of Research", Journal of Consumer Research, 31: 868-882.

Askegaard, S., Arnould, E. J. and Kjeldgaard, D. (2005) "Postassimilationist Ethnic Consumer Research: Qualifications and Extensions", Journal of Consumer Research, 32(1):160-170.

Baudrillard, J. (1997) Tuketim Toplumu, H.Delicayli \& F. Keskin (Translators), İstanbul: Ayrinti Publication.

Berry, J. W (1997) "Immigration, Acculturation, and Adaptation", Applied Psychology: An International Review, 46(1): 5-68.

Berry, J. W. (2003) "Conceptual Approaches to Acculturation", Chun et al. (eds.), Washington, DC, US: American Psychological Association. xxvii, Acculturation: Advances in Theory, Measurement, and Applied Research, pp. 17-37.

Berry, J. W; Kim, U. Power, S. Young, M. and Bujaki, M. (1989) "Acculturation Attitudes in Plural Societies," Applied Psychology, 38: 185-206.

Berry, J. W., Phinney, J. S., Sam, D. L. and Vedder, P. (2006) "Immigrant Youth: Acculturation, Identity and Adaptation", Applied Psychology: An International Review, 55(3): 303332.

Castles, S. and Davidson, A. (2000) Citizenship and Migration. Globalization and the Politics of Belonging, NY: Routledge, 2000 .

Cavusoglu, H. (2007) ““Yugoslavya-Makedonya” Topraklarından Turkiye'ye Gocler ve Nedenleri”, bilig Dergisi (Spring), 41: 123-154.

Cetin, T. (2008) “Bulgaristan'daki Soydaslarımızın Turkiye’ye Goc Etme Sureclerini Etkileyen Bazı Degiskenlerin İncelenmesi”, Turk Dunyasi Íncelemeleri Dergisi, 8(1): 55-75.

Cherrier, H., Munoz, C. and Wood, N. (2009) "Consumer Ethnic Identity: The Implications of Short Term Exposure to A Similar Culture", McGill \& Shavitt, Duluth, MN: Association for Consumer Research, Advances in Consumer Research, 36: 847-847.
Chung, E. (2000) "Navigating the Primordial Soup: Charting the Lived Worlds of the Migrant Consumer". Journal of Consumer Marketing, 17(1): 36-54.

Crockett, D. and Wallendorf, M. (2004) "The Role of Normative Political Ideology in Consumer Behavior", Journal of Consumer Research, 31: 511-528.

Doganay, F. (1996) Turkiye’ye Gocmen Olarak Gelenlerin Yerlesimi, http://ekutup.dpt.gov.tr/yerlesim/doganayf/gocmen.html, (20.03.2010).

Elliott, R. (1997) "Existential Consumption and Irrational Desire", European Journal of Marketing, 31(3/4): 285-296.

Erder, S. (2006) "Nerelisin Hemserim?” in Istanbul: Kuresel ile Yerel Arasinda, Keyder (ed.), İstanbul: Metis Yay.

Ger, G. and Østergaard, P. (1998) "Constructing Immigrant Identities in Consumption: Appearance Among the TurkoDanes", Alba \& Hutchinson (Eds.), Provo, UT: Association for Consumer Research, Advances in Consumer Research, 25: 48-52.

Gentry, J. W., Jun, S., Hyun, Y. J., Chun, S. and Commuri, S. (2002) "Behavioral Acculturation Among Korean Americans", Ramizwick \& Tu Ping (Eds.), Valdosta, GA: Association for Consumer Research, Asia Pacific Advances in Consumer Research, 5: 99-104.

Gronhaug, K., Gilly, M. and Penazola, L. (1993) "Barriers and Incentives in Consumer Acculturation”, Van Raaij \& Bamossy (Eds.), Provo, UT: Association for Consumer Research, European Advances in Consumer Research, 1: 278-286.

Hajdarpasic, E. (2008) "Out of the Ruins of the Ottoman Empire: Reflections on the Ottoman Legacy in South-eastern Europe", Middle Eastern Studies, 44(5): 715-734.

Hmida, M. H., Ozcaglar-Toulouse N. and Fosse-Gomez, M. H., (2009) "Towards an Understanding of Media Usage and Acculturation”, McGill \& Shavitt, Duluth, MN: Association for Consumer Research, Advances in Consumer Research, 36: 524-531.

Jun, S., Ball, A. D. and Gentry, J. W. (1993) "Modes of Consumer Acculturation", McAlister \& Rothschild (Eds.), Provo, UT: Association for Consumer Research, Advances in Consumer Research, 20: 76-82.

Jun, S., Gentry J. W., Ball, A. D. and Gonzalez-Molina, G. (1994) "Hispanic Acculturation Processes: Evidence Against Assimilation”, Cote \& Leong (Eds.), Provo, UT: Association for Consumer Research, Asia Pacific Advances in Consumer Research, 1: 80-86.

Kirisci, K. (2007) "Border Management and EU-Turkish Relations: Convergence or Deadlock”, Euro-Mediterranean Consortium for Applied Research on International Migration Research Report, Robert Schuman Centre for Advanced Studies, European University Institute, Florence. 
Kirisci, K. (2009) "Mirage or Reality? Post-national Turkey and Its Implication for Immigration”, CARIM Euro-Mediterranean Consortium for Applied Research on International Migration, Research Report, CARIM-RR 2009/14

Lieberman, B. (2006) "Nationalist Narratives, Violence Between Neighbours and Ethnic Cleansing in Bosnia-Hercegovina: a Case of Cognitive Dissonance?", Journal of Genocide Research, 8(3): 295-309.

Lindridge, A. (2009) "Acculturation, Religion and Consumption in Normative Political Ideology”, McGill \& Shavitt (Eds.), Duluth, MN: Association for Consumer Research, Advances in Consumer Research, 36: 16-17.

Makrides, M. V. (2007) "Religions in Contemporary Europe in the Context of Globalization", in Religion, Globalization and Culture, Beyer \& Beaman (Eds.), The Netherlands: Brill Academic Publishing, pp. 549-570.

Ogden, D. T., Ogden, J. R. and Schau, H. J. (2004) "Exploring the Impact of Culture and Acculturation on Consumer Purchase Decisions: Toward a Microcultural Perspective", Academy of Marketing Science Review, 2004(3), Available at http://www.amsreview.org/articles/ogden03-2004.pdf.

O'Guinn, T. C. and Faber, R. J. (1985) "New Perspectives on Acculturation: The Relationship of General and Role Specific Acculturation with Hispanics' Consumer Attitudes", Hirschman \& Holbrook (Eds.), Advances in Consumer Research, Provo, UT : Association for Consumer Research, 12: 113-117.

Oswald, L. R. (1999) "Culture Swapping: Consumption and the Ethnogenesis of Middle-Class Haitian Immigrants", Journal of Consumer Research, 25(4): 303-318.

Oksuz, H. (2006) Batı Trakya Turkleri (Makaleler), KaraM Yayınları: 17, Cagdas Sorunlar Dizisi: 3, Corum.

Ozcaglar-Toulouse, N. and Ustuner, T. (2009) "How Do Historical Relationships Between The Host and Home Countries Shape The Immigrants' Consumer Acculturation Processes?", McGill \& Shavitt (Eds.), Duluth, MN : Association for Consumer Research, Advances in Consumer Research, 36: 16-19.

Palumbo, F. A. and Teich I. (2004) "Market Segmentation Based on Level of Acculturation", Marketing Intelligence and Planning, 22(4): 472-484.

Penaloza, L. (1994) "Atravesando Fronteras/Border Crossings: A Critical Ethnographic Exploration of the Consumer Acculturation of Mexican Immigrants", Journal of Consumer Research, 21(1): 32-54.

Penaloza, L. (1995) "Immigrant Consumers: Marketing and Public Policy Considerations in the Global Economy”, Journal of Public Policy and Marketing, 14(1): 83-94.

Penaloza, L. (2008) "Consuming Community: The Impacts of Mainstream/Marginal Social Relations on Community Development", Lee \& Soman (Eds.), Duluth, MN: Association for Consumer Research, Advances in Consumer Research, 35: 33-34.

Penaloza, L. and Gilly, M. C. (1999) "Marketer Acculturation: The Changer and the Changed", Journal of Marketing, 63: 84104.
Quester, P. G. and Chong, I. (2001) "Validating Acculturation Models: The Case of the Australian-Chinese Consumers", Journal of Consumer Marketing, 18(3): 203-218.

Riedlmayer, A. (1993) "A Brief History of Bosnia-Herzegovina", The Bosnian Manuscript Ingathering Project, http://www. kakarigi.net/manu/briefhis.htm, (20.03.2010).

Rudmin, F. W. (2003) "Critical History of the Acculturation Psychology of Assimilation, Separation, Integration, and Marginalization”, Review of General Psychology, 7(1): 3-37.

Sandikci, O.; Ekici A. and Tari, B. (2006) "Consumer Acculturation as a Dialogical Process: Case Studies from Rural-to-Urban Migrants in Turkey", Pechmann \& Price (Eds.), Duluth, MN: Association for Consumer Research, Advances in Consumer Research, 33: 429-434.

Shoham, A., Segev S. and Ruvio A. (2009) "A Comprehensive Model for Hispanics' Acculturation: Antecedents and Impacts on Store and Brand Loyalty", McGill and Shavitt (Eds.), Duluth, MN: Association for Consumer Research, Advances in Consumer Research, 36: 17-18.

Tari, B., Sandikci, Ö. and Omeraki, S. (2008) "Exploring Needs, Desires, and Hopes: A Study of Impoverished Migrant Consumers", Lee \& Soman (Eds.), Duluth, MN: Association for Consumer Research, Advances in Consumer Research, 35: 850-850.

Ulker, E. (2007) "Assimilation of The Muslim Communities in The First Decade of The Turkish Republic (1923-1934)", European Journal of Turkish Studies, http://ejts.revues.org/ index822.html, (23.03.2010).

Ustuner, T. and Holt, D. B. (2007) "Dominated Consumer Acculturation: The Social Construction of Poor Migrant Women's Consumer Identity Projects in a Turkish Squatter", Journal of Consumer Research, 34(1): 41-56.

Ucok, M. and Kjeldgaard, D. (2006) "Consumption Practices in Transnational Social Spaces: A Study of Turkish Transmigrants", Ekstrm \& Brembeck (Eds.), Duluth: MN: Association for Consumer Research, European Advances in Consumer Research, 7: 431-436.

Velikonja, M. (2003) Religious Separation and Political Intolerance in Bosnia-Herzegovina, Rang'ichi, Ng'inja (Translator), College Station, TX, USA: Texas A \& M University Press.

Wamwara-Mbugua, L. W., Cornwell, T. B. and Boller, G. (2006) "Triple Acculturation: The Role of African Americans in the Consumer Acculturation of Kenyan Immigrants", Pechmann \& Price (Eds.), Duluth, MN : Association for Consumer Research, Advances in Consumer Research, 33: 428-428.

Wilson, R. T. (2007) "Acculturation and Discrimination in the Global Market Place: The Case of Hispanics in the U.S.", Journal of International Consumer Marketing, 20(1): 67-78.

Wood, W. B. (1994) "Forced Migration: Local Conflicts and International Dilemmas", Annals of the Association of American Geographers, 84(4): 607-634. 